DOI: $10.14451 / 2.130 .29$

\title{
ВИДЫ ОРГАНИЗАЦИЙ, СОЗДАВАЕМЫХ ДЛЯ ОСУЩЕСТВЛЕНИЯ И ЗАЩИТЫ ИНТЕЛЛЕКТУАЛЬНЫХ ПРАВ В РОССИИ
}

\author{
(c) 2019 Барковская Людмила Евгеньевна \\ соискатель
}

Российская государственная академия интеллектуальной собственности, Россия, Москва

В данной статье автором предложено определение понятия «инфраструктура интеллектуальной собственности», а также разработана ее структура, описаны ее основные субъекты (участники). Особое внимание автор уделяет правовому статусу ассоциаций и союзов, осуществляющих свою деятельность в сфере интеллектуальной собственности. Делается вывод о необходимость законодательного закрепления норм о таких организациях в части 4 Гражданского кодекса Российской Федерации.

Ключевые слова: инфраструктура интеллектуальной собственности, организации по коллективному управлению правами, Всероссийское общество изобретателей и рационализаторов, Союз писателей России, Союз композиторов России.

Построение инновационной экономики невозможно без увеличения объемов результатов интеллектуальной деятельности (далее - РИД) и средств индивидуализации, вовлекаемых в гражданский оборот. Коммерциализация интеллектуальной собственности (далее - ИС) возможна двумя основными путями: за счет использование в собственном производстве и бизнесе, либо за счет совершения сделок с исключительными правами на РИД. Как для первого, так и для второго варианта коммерциализации необходимо создание востребованных РИД.

В связи с этим важнейшим фактором достижения цели формирования рынка ИС и построения инновационной экономики является формирование инфраструктуры ИС. Инфраструктура (англ. - Infrastructure, от лат. Infra - под + Structura - строение) - это комплекс взаимосвязанных обслуживающих структур, составляющих и/или обеспечивающих основу для решения проблемы (задачи) [1]. Применительно к теме статьи, инфраструктура ИС представляет собой систему субъектов и объектов, которая обеспечивает достижение цели построения инновационной экономики, основанной на знаниях. Иными словами, инфраструктура ИС - это совокупность профессиональных посредников, представителей, а также других лиц, которые осуществляют помощь авторам и правообладателям РИД в достижении основных целей создания и использования ИС - создания новых РИД и их коммерциализации.

По мнению автора, в условиях рыночной эко- номики такая инфраструктура должна функционировать, в первую очередь, децентрализовано и преимущественно формироваться негосударственными институтами, однако государство играет в ней важную системообразующую роль. В этой связи особое значение имеет правовой статус различных организаций, осуществляющих деятельности в сфере интеллектуальной собственности и формирующих инфраструктуру ИС.

Если исходить из предложенного понимания инфраструктуры ИС, то ее составляющими могут являться:

1. Государственные органы и организации, осуществляющие функции нормативно-правового регулирования ИС, контроля и надзора. K таким органам и организациям относятся, в частности, Министерство экономического развития Российской Федерации, Министерство культуры Российской Федерации, Федеральная служба по интеллектуальной собственности (Роспатент) и подведомственные учреждения, а также другие органы и учреждения, включая суды, рассматривающие споры в сфере ИС.

2. Профессиональные общества и объединения, осуществляющие представление интересов творческих профессий, бизнеса и т.п. K таким организациям следует отнести Союз композиторов России, Союз писателей России, Союз журналистов России, Всероссийское общество изобретателей и рационализаторов и другие организации. Они представляют собой некоммерческие организации, созданные в целях 
представления интересов соответствующих категорий авторов и правообладателей и защиты их интересов. Особое место среди них занимает Торгово-промышленная палата Российской Федерации (далее - ТПП РФ), несмотря на то, что вопросы ИС не являются для ТПП РФ основными. Данные участники инфраструктуры ИС являются ее важными участниками, в связи с чем считаем необходимым остановиться на них подробнее ниже.

3. Организации по коллективному управлению правами. Данные организации создаются и функционируют в соответствии со статьями 1242-1244 [2] Гражданского кодекса Российской Федерации (далее - ГК РФ) в целях защиты имущественных интересов авторов и правообладателей объектов авторского права и смежных прав, что отличает их от организаций, отмеченных в пункте два данного списка. Организациям по коллективному управлению была посвящена отдельная статья автора [3]. К данным организациям относятся, в частности, Российское авторское общество, Всероссийская организация интеллектуальной собственности, Российский союз правообладателей и другие подобные организации.

4. Коммерческие организации, оказывающие различного рода услуги в сфере ИС, в том числе адвокатские конторы и др. Данные субъекты являются важным элементом инфраструктуры ИС, однако, как правило, оказание услуг в сфере ИС не является основным видом деятельности указанных организаций.

Итак, негосударственные субъекты инфраструктуры ИС достаточно разнообразны и многочисленны. Некоторые из них специализируются исключительно на интеллектуальной собственности, для других данная сфера не является профильной, как например, для ТПП РФ и различных юридических фирм. Некоторые же в настоящее время уже получили адекватное правовое регулирование, их статус и деятельность определены ГК РФ и иными нормативно-правовыми актами. К таким организациям, например, относятся организации по коллективному управлению авторскими и смежными правами. Вместе с тем, имеется целый ряд организаций, которые выполняют крайне важную в рамках страны функцию в сфере ИС, но роль которых в развитии ИС не определена в нормах части четвертой ГК РФ. К ним относятся профессиональные общества и объединения. В связи с этим считаем необходимым более детально остановиться на той роли, которую данные организации играют в инфраструктуре ИС, и анализе их полномочий. Для этого обратим внимание на такие организации, как Союз композиторов России, Союз писателей России и Всероссийское общество изобретателей и рационализаторов.

\section{Союз композиторов России.}

Союз композиторов России является всероссийской общественной организацией. В соответствии с п. 2.1. Устава Всероссийской общественной организации «Союз композиторов России» [4], целью ее деятельности является содействие, представление, реализация и защита интересов членов организации в их профессиональной деятельности. Среди конкретных целей и задач п. 2.2. устава устанавливает защиту творческих, авторских и гражданских прав и интересов членов организации.

Таким образом, можно сделать вывод о том, что деятельность Союза композиторов заключается в представлении, продвижении и защите интересов своих членов. Однако, несмотря на кажущуюся простоту данной формулировки, следует иметь ввиду, что в первую очередь речь идет не о представительстве по смыслу ст. 182 ГК РФ [5]. Если обратить внимание на п. 2.3. устава данной организации, то становится очевидным, что компетенция и действия, которые Союз композиторов вправе осуществлять для достижения уставных целей направлена на взаимодействие с государственными органами, участие в выработке социально-экономической политики, разработке проектов законов и нормативных правовых актов, проведение активной общественной деятельности и тому подобное. Конечно, в данном пункте также говорится, что Союз вправе оказывать своим членам информационно-консультативную, методическую и правовую помощь, однако, из содержания п. 2.3. следует, что представление интересов членов Союза необходимо понимать как консолидированное выражение воли определенной группы лиц (композиторов и иных членов общества) при взаимодействии с государственной властью, общественными институтами и международными организациями. В этом ключе значение деятельности данного Союза приобретает особое значение, большее, чем простое представительство авторов и правообладателей в гражданско-правовых отношениях. 


\section{Союз писателей России.}

Аналогичным образом сформулированы цели и задачи Союза писателей России. П. 2.1 устава Общероссийской общественной организации «Союз писателей России» [6] закрепляет, что Союз имеет своей целью объединение писателей России в творческое содружество для создания условий их профессионального роста, а также для защиты законных прав и интересов писателей. Данная формулировка является более широкой, чем определение цели в уставе Союза композиторов, и позволяет в совокупности с положениями пунктов 2.2. и 2.3. устава сделать следующий важный вывод. Данная организация осуществляет не только представление интересов писателей как категории граждан в отношениях с государством и обществом, и не просто оказывает правовую и иную помощь (в том числе осуществляя полномочия представителя в ряде случаев), но ее деятельности также направлена на создание в обществе условий для развития литературного творчества.

Эта цель является очень важной в системе инфраструктуры ИС. Если вновь обратиться к структуре инфраструктуры, то станет очевидным, что, не считая государственных органов, ее основную массу составляют субъекты, осуществляющие представительские и посреднические функции. Однако для развития рынка ИС и становления инновационной экономики не менее важное значение имеет не только возможность обратиться за помощью к профессиональным посредникам и специалистам в сфере ИС, но и наличие необходимых условий для осуществления творческой деятельности и реализации ее результатов.

Всероссийское общество изобретателей и рационализаторов (далее - ВОИР).

Наиболее показательным в контексте данной статьи является пример Общественной организации «Всероссийское общество изобретателей и рационализаторов», так как ее деятельность практически всецело сосредоточена вокруг вопросов интеллектуальной собственности (в первую очередь промышленной собственности). Статья 5 устава Общественной организации «Всероссийское общество изобретателей и рационализаторов» закрепляет следующие цели деятельности организации:

- объединение физических лиц: изобретателей, рационализаторов, самодеятельных авторов, патентообладателей, других лиц, содей- ствующих развитию технического творчества, а также юридических лиц - общественных объединений, для совместного решения задач по защите их прав, законных интересов и удовлетворения их потребностей в указанной сфере;

- создание организационных, экономических, социальных и правовых условий для проявления и реализации творческих возможностей членов Общества, усиления их социальной защищенности;

- оказание практической помощи изобретателям и рационализаторам - членам Общества в разработке и внедрении их предложений;

- защита, в случаях и порядке, установленных законодательством Российской Федерации, прав и законных интересов членов Общества в сфере интеллектуальной (в том числе промышленной) собственности [7].

На основе анализа данного положения устава можно подчеркнуть, что цели союзов и ассоциаций, осуществляющих деятельность в сфере интеллектуальной собственности можно сгруппировать следующим образом:

1) консолидация представителей творческих профессий, а также авторов и правообладателей для целей представления их интересов как социальной группы в отношениях с государственной властью и обществом;

2) создание условий для стимулирования творчества (в случае с ВОИР технического творчества);

3) оказание юридической помощи членам общества (в том числе, представительство).

Причем следует особо отметить, что автор специально обозначил обобщенные цели именно в таком порядке, так как первая цель заявляется в уставах всех трех исследованных организациях первой среди других, в то время как остальные перечисляются уже после. Также второй цели уделено немало подпунктов и задач во всех трех уставах, в то время как оказание юридической помощи членам организаций во всех изученных уставах указывается лишь по одному разу

В качестве подтверждения данного тезиса приведем пример с официального сайта ВОИР, где в сжатой форме доступным языком сформулированы задачи организации. Задачи ВОИР состоят:

- в активном взаимодействии с государственными органами и институтами развития при разработке и реализации программ и про- 
ектов, совершенствовании законодательства и нормативной правовой базы в сфере изобретательской и рационализаторской деятельности в целях защиты прав и интересов членов Общества;

- в формировании, содействии и стимулировании общественной инициативы, направленной на активизацию изобретательской и рационализаторской деятельности в Российской Федерации с опорой на опыт и традиции, сформировавшиеся на протяжении десятилетий несколькими поколениями отечественных изобретателей;

- в сохранении, популяризации и распространении знаний и опыта в сфере изобретательства и рационализаторства с использованием современных информационных технологий и максимальном вовлечении в процесс технически способной и активной молодежи;

- в освещении достижений в области изобретательской и рационализаторской деятельности в средствах массовой информации с привлечением широкого внимания общественности, промышленных и инвестиционных партнеров, в том числе международных, с целью внедрения разработок и обеспечения притока дополнительных инвестиций в экономику России [8].

Таким образом, перечисление задач включает представление интересов изобретателей и рационализаторов в отношении с государством и обществом, а также создание условий, стимулирующих техническое творчество в России, в то время как оказание юридической и иной помощи членам организации здесь не упоминаются вовсе.

Также, по мнению автора, следует особо подчеркнуть такую задачу ВОИР, как формирование, содействие и стимулирование общественной инициативы, направленной на активизацию изобретательской и рационализаторской деятельности в Российской Федерации с опорой на опыт и традиции, сформировавшиеся на про- тяжении десятилетий несколькими поколениями отечественных изобретателей. Сохранение традиций отечественного изобретательства, которые сложились в Советском Союзе, является крайне важным ввиду их преимуществ, благодаря которым Россия до сих пор сохраняет технологической лидерство в ряде наукоемких отраслей. Однако данные традиции опираются на ныне не действующее законодательство СССР. Как справедливо отмечает О.В. Ревинский, уже отмененные законы и другие акты РФ и даже СССР можно применять в тех случаях, когда они не входят в противоречие с действующим Гражданским кодексом [9]. В этой связи опыт ВОИР является неоценимым, так как организация была основана еще в СССР и в 2017 году отметила 85-летний юбилей.

В связи с этим считаем необходимым особо подчеркнуть, деятельность различных ассоциаций и союзов в сфере ИС направлена, в первую очередь, на консолидацию интересов авторов и правообладателей и их представлении в отношениях с государственной властью, обществом и международными организациями и институтами. Эта цель является неоценимо важной, так как позволяет влиять на формирование государственной политики и общественное отношение к творческой деятельности, что способствует формированию в России такой среды, которая способствовала проявлению творческих способностей граждан, более эффективной коммерциализации ИС и становлению атмосферы уважительного отношения к ИС.

Вместе с тем, данная важнейшая функция и роль ассоциаций и союзов в сфере ИС никоим образом не закреплена в части 4 ГК РФ, что, по мнению автора, не способствует эффективному взаимодействию данных организаций с государством и обществом. В связи с этим считаем необходимым включить в часть 4 ГК РФ нормы, регламентирующие роль данных организаций в укреплении законности в сфере ИС.

\section{Библиографический список}

1. URL: http://www.glossary.ru/cgi-bin/gl_sch2.cgi?RIt(wgxywzqyzwg

2. Гражданский кодекс Российской Федерации. Часть четвертая. Федеральный закон от 18.12.2006 № 230-Ф3 (ред. от 03.07.2016) // СПС КонсультантПлюс.

3. Барковская Л.Е. Новеллы правового регулирования организаций по управлению правами на коллективной основе // Копирайт. 2018. №1. С. 24-32.

4. Устав Всероссийской общественной организации «Союз композиторов России» // http://unioncomposers.ru/ upload/ustav.pdf 
5. Гражданский кодекс Российской Федерации. Часть первая. Федеральный закон от 30.11.1994 № 51-Ф3 (ред. от 29.07.2017) // СПС КонсультантПлюс.

6. Устав Общероссийской общественной организации «Сюз писателей России» // http://rospisatel.ru/ustav. htm

7. Устав Общественной организации «Всероссийское общество изобретателей и рационализаторов» // http:// www.ros-voir.ru/ru/ustav-page

8. http://www.ros-voir.ru/ru/structure-page

9. Ревинский О.В. Право промышленной собственности. Курс лекций. / О.В. Ревинский. М. : Юрсервитум, 2017. $-50 \mathrm{C}$. 